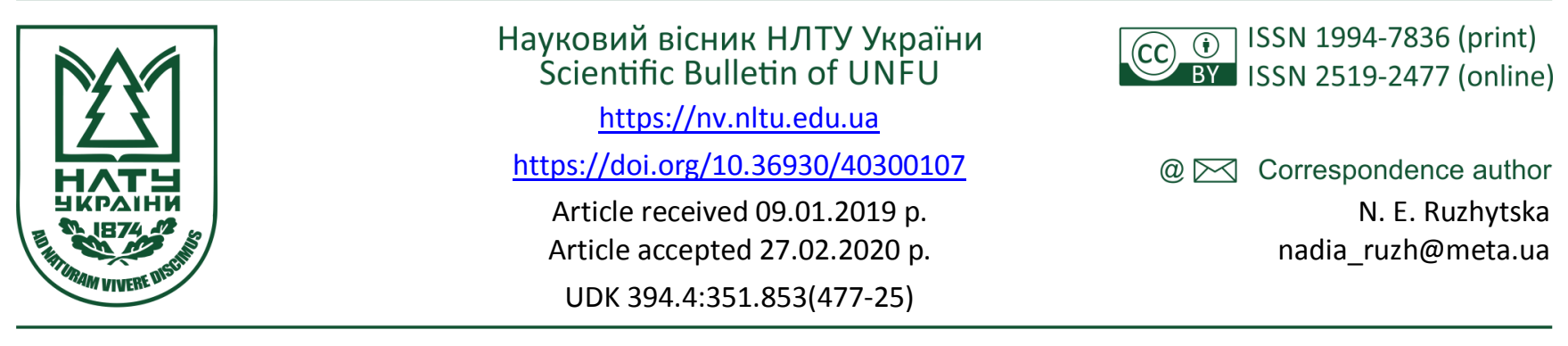

Н. Е. Ружицька, І. О. Сидоренко

Національний університет біоресурсів і природокористування України, м. Київ, Україна

\title{
ОСОБЛИВОСТІ РЕГУЛЮВАННЯ ПРАВОМІРНОГО ВИКОРИСТАННЯ ТЕРИТОРІЙ ОБ'ЄКТІВ НЕРУХОМОЇ СПАДЩИНИ ІСТОРИЧНОГО ЦЕНТРУ МІСТА КИЄВА
}

\begin{abstract}
Ключовою особливістю розвитку держави на світовому рівні є збереження та охорона історичної спадщини. Державне регулювання щодо цього питання в Україні на сьогодні потребує узгодження чинного законодавства про охорону культурної спадщини з міжнародно-правовими стандартами, аналізу та впровадження світового досвіду зі збереження об'єктів нерухомої спадщини та дотримання рекомендацій міжнародних організацій щодо охорони цінних історичних територій у структурі міста. Актуальним є пошук шляхів оптимізації та раціоналізації правового забезпечення державного регулятивного впливу у сфері охорони культурної спадщини. Удосконалення нормативно-правового регулювання сприяє покращенню економічного рівня держави, що водночас, $є$ підгрунтям для раціональної роботи та реалізації функцій державного управління щодо об'єктів історичної нерухомої культурної спадщини. Аналіз сучасного досвіду збереження історичного середовища та формування принципів ревіталізації цінного архітектурно-естетичного історичного ландшафту міста є важливою науковою проблемою, що охоплює як теоретичні, так і практичні особливості розвитку містобудування. Для сучасного стану історичних міст України характерні проблеми, пов'язані зі збереженням об'єктів нерухомої спадщини, що призводить до необхідності удосконалення історико-архітектурної композиції міст та забезпечення неповторності середовища. Об'єкти історичної спадщини періоду раннього та розвиненого Середньовіччя (V-XXI ст.) було сформовано в часи, що характеризуються змінами як у глобальному масштабі, так і в окремих містах України. Перетворення у Києві охоплюють політичну, економічну й соціальну сфери суспільного життя, які безперечно впливали на формування інфраструктури міста. Вивчення актуальних підходів до збереження історичних об'єктів, втілення котрих приведе у подальшому до раціонального використання територій та покращення економічного потенціалу, є важливими питаннями розвитку міста. У науковій роботі розгляду підлягають сучасні наукові підходи щодо питань охорони історичного середовища.
\end{abstract}

Ключові слова: збереження; охорона; пам'ятка; міське середовище; культурна спадщина; історико-археологічна нерухома спадщина; історичний центр.

Вступ. На сьогодні важливим питанням є збереження та інтегрування об'єктів нерухомої культурної спадщини у структуру міста, а охорона цих територій та об'єктів є складовою частиною процесу збереження спадщини. Одним з головних завдань розвитку міського середовища $є$ досягнення балансу між збереженням історичної складової та невід'ємними прогресивними змінами міста [1].

Регулювання правомірних дій щодо об'єктів історичного центру неможливе без забезпечення правової політики охорони цих територій [3]. Інтеграція та адаптація історичних об'єктів до сучасних умов міста дає змогу розширити можливості економічного та туристичного потенціалу розвитку міста загалом $[4,5]$. Впровадження перспективних шляхів експлуатації об'єктів нерухомої культурної спадщини підвищить економічну функцію міста шляхом покращення туристичного зацікавлення до цих історичних територій та об'єктів, що на них розташовані [2]. Забезпечення сучасних підходів та шляхів щодо реконструкції історичних територій стимулює комерційну діяльність і покращує рівень надан- ня міських послуг [6]. Збереження та охорона нерухомої культурної спадщини підвищує рівень обізнаності населення та привертає увагу суспільства до вагомості та значущості історичної складової міського середовища [7].

Об'єкт дослідження - території об'єктів епохи раннього та розвиненого Середньовіччя історичного центру Києва.

Предмет дослідження - методи і засоби регулювання правомірного використання територій об'єктів нерухомої спадщини історичного центру міста Києва.

Мета дослідження - визначення особливостей регулювання правомірного використання територій об'єктів нерухомої спадщини історичного центру міста Києва, що дасть змогу вирішити проблему ефективного їх збереження.

Для досягнення зазначеної мети потрібно вирішити такі основні завдання дослідження:

- проаналізувати принципи регулювання питань охорони цінних історичних територій у міському середовищі на прикладі рекомендацій, розроблених ЮНЕСКО;

\section{Інформація про авторів:}

Ружицька Надія Едуардівна, аспірант, кафедра ландшафтної архітектури та фітодизайну. Email: nadia_ruzh@meta.ua

Сидоренко Ірина Олександрівна, канд. біол. наук, доцент, кафедра ландшафтної архітектури та фітодизайну.

Email: i_sido@ukr.net

Цитування за ДСтУ: Ружицька Н. Е., Сидоренко І. О. Особливості регулювання правомірного використання територій об'єктів нерухомої спадщини історичного центру міста Києва. Науковий вісник НЛтУ України. 2020, т. 30, № 1. С. 45-48.

Citation APA: Ruzhytska, N. E., \& Sidorenko, I. O. (2020). Legal regulation by the use of territories at the historical center in Kiev. Scientific Bulletin of UNFU, 30(1), 45-48. https://doi.org/10.36930/40300107 
- визначити основні проблеми у галузі охорони культурної спадщини України;

- зробити висновки та надати рекомендації щодо особливостей регулювання правомірного використання територій об'єктів нерухомої спадщини.

Методи дослідження. Для вирішення поставлених завдань застосовано методи системного та порівняльного аналізу, іконографічний метод. Інформаційною базою є: законодавчі документи, історіографічні, іконографічні та письмові джерела, а також виконані матеріали натурних обстежень об'єктів нерухомої культурної спадщини.

Наукова новизна дослідження полягає в тому, що отримала подальший розвиток методика регулювання правомірного використання територій об'єктів нерухомої спадщини історичного центру міста Києва, особливість якої базується на наукових принципах, запроваджених на міжнародному рівні.

Практична значущцість отриманих результатів дослідження зводиться до вироблення рекомендацій, суть яких полягає в тому, що роботи, пов'язані з реконструкцією, реставрацією, консервацією та відновленням об'єктів нерухомої спадщини історичного центру, повинні базуватись тільки на міжнародних наукових принципах. Окрім цього, за умов сучасної урбанізації міського простору необхідно не допускати збільшення щільності та масштабів споруд біля пам'яток історичної спадщини, оскільки з плином часу це призводить до руйнування історичних територій.

Аналіз літературних джерел. Питання збереження об'єктів нерухомої спадщини та аналіз зарубіжного досвіду вивчали Т. І. Катаргіна, В. М. Вакуленко, І. В. Валентюк, Н. В. Терес. Дослідження у сфері охорони нерухомої спадщини історичних міст здійснювали: О. А. Пламеницька, Ю. О. Григор'єв, Г. О. Комаров, О. А. Панченко, С. С. Корольонок. Правові особливості наукових досліджень 3 питань охорони нерухомої спадщини грунтується на чинному законодавстві та на міжнародних конвенціях. У сучасному суспільстві питання збереження історичних об'єктів у структурі міста відіграє ключову роль, в основу сучасного світового досвіду збереження історичної забудови міст покладено "Рекомендації ЮНЕСКО про збереження і сучасну роль історичних ансамблів", ухвалених 26.11.1976 р. Цим документом прийнято низку нормативних правил щодо виконання робіт у структурі історичного середовища. В Україні правове регулювання здійснюється на основі низки законів і постанов, що спираються на чинне Європейське законодавство.

Викладення основного матеріалу дослідження. Узагальнюючи принципи регулювання за прикладом рекомендацій, розроблених ЮНЕСКО з питань охорони цінних історичних територій у міському середовищі, можна виділити заходи правового регулювання, містобудівельні та заходи, спрямовані на регламентацію реноваційних робіт. Вивчення досвіду правомірного використання територій об'єктів нерухомої культурної спадщини дає змогу систематизувати напрацювання в галузі охорони та збереження історичних територій.

Правове регулювання визначає переваги та недоліки сучасного законодавства та шляхом аналізу виділяє ключові принципи правоохоронних дій щодо охоронних територій. Правове регулювання охоплює дії щодо регулювання та обмеження господарської діяльності та методи охорони територій історичних ареалів у структурі міста. За допомогою цього принципу здійснюється раціональне використання та експлуатація об'єктів, розташованих в історичній території.

Містобудівельне регулювання розглядає вивчення цих територій, опираючись на потребу реорганізації містобудівельної ситуації відповідно до сучасних умов. Містобудівельне регулювання забезпечує дотримання традиційного характеру середовища історичних ареалів та збереження місто-формувальної ролі загалом. Адаптація історичних об'єктів до сучасної забудови $\epsilon$ найважливішим завданням містобудівельного регулювання. Виявлення синтезу між історичними та сучасними об'єктами є передумовою до вирішення функціональних та містоформувальних задач.

Регламентація реноваційних робіт - це комплексне поняття, що охоплює такі методи збереження, як: реконструкція, реставрація, консервація та відновлення. Цей принцип забезпечує збереження цінних історичних розпланувань і забудов, озеленення та упорядження виразних елементів ландшафту. Регламентується порядок та умови для огляду пам'яток та історичного ареалу загалом. Також визначається ступінь та характер робіт, опираючись на цінність наявних об'єктів культурної спадщини, територіальне розташування охоронної зони в історичному ареалі та особливості об'ємно-просторового устрою історичного ареалу. Правомірне дотримання та застосування цих процесів дає змогу зберегти території об'єктів нерухомої культурної спадщини без порушення їх цілісної структури.

Формулювання завдань збереження історичного центру є актуальним, оскільки за сучасної урбанізації, що веде до значного збільшення масштабів і щільності забудови, окрім загрози прямого руйнування історичних ансамблів, існує реальна загроза того, що райони новобудов можуть заподіяти шкоди оточенню і характерові історичних ансамблів. Сучасні реноваційні зміни впливають на об'єкти нерухомої культурної спадщини історичних центрів міст. Яскравими прикладами можуть слугувати більшість історичних Європейських міст, які дають приклади як руйнівного поводження 3 історичними центрами (Бухарест, Румунія), так і міста 3 оптимальним балансом сучасної забудови й історичної частини (Варшава, Польща), так і до повного збереження архітектури планування, що віднесені до певної історичної епохи (Прага, Чехія).

Варто зазначити, що незважаючи на концентрацію історичних забудов, ареалів та важливих для світової спадщини територій у Києві, в питаннях охорони та правового регулювання є певні недоліки. Управління у сфері охорони культурної спадщини в Україні має комплексний характер. Регулювання відносин відбувається на основі базового Закону "Про охорону культурної спадщини" та додаткових законодавчих і підзаконних актів. На законодавчому рівні не схвалено єдиного закону, який би регулював усі особливості суспільних відносин у сфері охорони культурної спадщини. Труднощі щодо реалізації функцій державного управління у сфері охорони об'єктів нерухомої культурної спадщини виникають на підставі неузгодженості багатьох правових документів, що призводить до недотримання в процесі архітектурно-містобудівної діяльності принципів регулювання правомірного використання територій цих об'єктів. Законодавство України потребує впроваджен- 
ня сучасних підходів до регулювання чинних нормативно-правових актів, прийняття концепцій та програм, що відповідатимуть та будуть регламентовані документами ЮНЕСКО, ІКОМОС та рішеннями ради Свропи.

На території Києва збережена значна кількість безцінних пам'яток архітектури та містобудування. Роз- гляд об'єктів за трьома принципами регулювання дасть змогу виявити позитивні та проблемні питання на цих історичних територіях та слугуватиме підосновою для реалізації сучасних рекомендацій щодо правомірного використання об'єктів (таблиця).

Таблиця. Аналіз регулювання правомірного використання територій об'єктів епохи раннього та розвиненого Середньовіччя історичного центру м. Кисва

\begin{tabular}{|c|c|c|}
\hline Історичний об'єкт & \begin{tabular}{c|} 
Наявна \\
ситуація
\end{tabular} & Характеристика \\
\hline \multicolumn{3}{|r|}{ Правове регулювання } \\
\hline Городище Кия & + & Визначено межі та режим використання даних історичних територій \\
\hline Десятинна церква & + & Обмежено господарську діяльність \\
\hline Софійський собор & + & Охорона території цих об'єктів у структурі міста \\
\hline Золоті ворота & + & Забезпечено захист об'єктів від загрози знищення, руйнації чи ушкодження \\
\hline Іринський собор & - & Визначено межі території \\
\hline Георгіївська церква & - & $\begin{array}{l}3 \text { огляду на знищення надземної частини об'єктів ускладнено проведення заходів щодо їх охо- } \\
\text { рони у структурі міста }\end{array}$ \\
\hline \multicolumn{3}{|c|}{ Містобудівельне регулювання (характер щільності, висотності та перспектив забудови в історичній частині міста) } \\
\hline Городище Кия & +- & Забезпечено інженерно-транспортну інфраструктуру \\
\hline Десятинна церква & +- & $\begin{array}{l}\text { Відбувається моніторинг стану об'єкта } \\
\text { Здійснюється архітектурно-будівельний контроль щодо об'єктів } \\
\text { забезпечено вдалі перспективи огляду об'єкта } \\
\text { Ведеться контроль щодо перевищення рівня висотності навколишньої забудови } \\
\text { Втрачено автентичний вигляд об'єкта }\end{array}$ \\
\hline Софійський собор & + & $\begin{array}{l}\text { Забезпечено інженерно-транспортну інфраструктуру } \\
\text { Відбувається моніторинг стану об'єкта } \\
\text { Здійснюється архітектурно-будівельний контроль щодо об'єктів } \\
\text { Забезпечено вдалі перспективи огляду об'єкта } \\
\text { Не перевищено рівень висотності навколишньої забудови } \\
\text { Збережено автентичний вигляд об'єкта }\end{array}$ \\
\hline Золоті ворота & + & $\begin{array}{l}\text { Забезпечено інженерно-транспортну інфраструктуру } \\
\text { Відбуваєтья моніторинг стану об'єкта } \\
\text { Здійснюється архітектурно-будівельний контроль щодо об'єктів } \\
\text { Рівень висотності забудови навколо об'єкта не є перевищеним, проте навколишня забудова } \\
\text { спричиняє тиск на зорове сприйняття масштабності історичного об'єкта } \\
\text { Не відтворено автентичний вигляд об'єкта }\end{array}$ \\
\hline Іринський собор & - & Не забезпечено зону охорони об'єкта в міському середовищі \\
\hline Георгіївська церква & - & Не відтворено автентичний вигляд об'єктів \\
\hline \multicolumn{3}{|r|}{ Регламентація реноваційних робіт на території історичних об'єктів } \\
\hline Городище Кия & - & Забезпечено роботи щодо часткової консервації об'єкта \\
\hline Десятинна церква & - & $\begin{array}{l}\text { Проведено планувальну та ландшафтну організацію території об'єкта } \\
\text { Забезпечено діяльність щодо обслуговування та догляду за територією об'єкта }\end{array}$ \\
\hline Софійський собор & + & $\begin{array}{l}\text { Вживають заходів щодо реконструкції будівель і споруд } \\
\text { Проведено планувальну організацію території об'єкта } \\
\text { Забезпечено просторово-архітектурну цілісність історичної території } \\
\text { Забезпечено діяльність щодо обслуговування та догляду за територією об'єкта } \\
\end{array}$ \\
\hline Золоті ворота & + & $\begin{array}{l}\text { Проведено відновлення та реконструкцію без відтворення автентичного вигляду об'єкта } \\
\text { Проведено планувальну та ландшафтну організацію території об'єкта } \\
\text { Забезпечено діяльність щодо обслуговування та догляду за територією об'єкта }\end{array}$ \\
\hline Іринський собор & - & Не забезпечено просторово-архітектурну цілісність історичної території \\
\hline Георгіївська церква & - & $\begin{array}{l}3 \text { огляду на повне знищення наземної частини об'єкта, проведення діяльності щодо обслугову- } \\
\text { вання є неможливим } \\
\text { Відсутній доступ до залишків пам'яток через сучасний інфраструктурний розвиток міста }\end{array}$ \\
\hline
\end{tabular}

Проаналізувавши особливості регулювання правомірного використання території об'єктів нерухомої культурної спадщини, які територіально розміщені в історичній частині Києва, варто зазначити, що не дотримання принципів регулювання процедур використання територій об'єктів, встановлених у зонах охорони, призводить до зміни архітектурно-просторового сприйняття історичного масштабу міста на фоні об'єктів сучасної забудови. Будівлі, що зведені з істотними перевищеннями висотних обмежень та просторових параметрів, призводять до зміщення акцентів в історичному середовищі, що водночас, зумовлює знецінення унікальної ландшафтно-просторової композиції міста, нівелюван- ня пам'яток архітектури в міському просторі, а іноді провокує їх повне знищення.

\section{Висновки:}

1. З'ясовано, що для вирішення завдань збереження та управління об'єктами, територіально розміщених в історичному центрі Києва, необхідне забезпечення законодавчих і регуляторних заходів. Об'єкти нерухомої спадщини на законодавчому рівні повинні бути захищені від ушкоджень, пов'язаних з неправомірним використанням територій та не доцільною роботою у межах охоронних ареалів.

2. Виявлено, що території об'єктів нерухомої спадщини історичного центру та містобудівельну територію нав- 
коло нього потрібно розглядати сукупно як цілісне угруповання.

3. Встановлено, що роботи, пов'язані з реконструкцією, реставрацією, консервацією та відновленням об'єктів нерухомої спадщини історичного центру, повинні базуватись на наукових принципах, запроваджених на міжнародному рівні.

4. Доведено, що за умов сучасної урбанізації міського простору необхідно не допускати збільшення щільності та масштабів споруд біля пам'яток історичного ареалу, оскільки 3 плином часу це призводить до руйнування історичних територій.

Шкода, але Україна у питанні регулювання правомірного використання територій історичного центру поступається закордонним підходам і методикам опрацювання цієї проблематики. Правомірними можуть бути реставраційні відтворення втрачених домінант або усунення дисонуючих об'єктів для розкриття історичної вертикальної композиції містобудівного утворення, його панорами чи силуету.

Допускається також нове будівництво на вільних ділянках, за умови дотримання історичних принципів планування кварталу та ділянки. 3 огляду на таку різносторонність процесів регенерації та відтворення історичного середовища, нами було визначено вимоги до відтворення житлової забудови центральних частин малих історичних міст, які диктують, що історична вулична мережа, величина та конфігурація кварталів, спосіб їх забудови, парцеляція, висотність та характер забудови повинні враховуватися при розробленні проектної документації.
Отже, об'єкти нерухомої спадщини можуть зробити видатний внесок у збереження та розвиток культурних і соціальних цінностей нації, що, водночас, зумовить значне архітектурне збагачення культурної спадщини не тільки нашої держави, але і світу.

\section{References}

1. Bandarin, F., \& Van Oers, R. (2012). The Historic Urban Landscape: Managing Heritage in an Urban Century. (1st ed.). Blackwell Publishing Ltd.: Hoboken, NJ, USA.

2. Barrera-Fernández, D., Hernández-Escampa, M., \& Balbuena, A. (2016). Tourism management in the historic city. The impact of urban planning policies. Int. J. Sci. Manag. Tour., 2, 349-367.

3. Sassen, S. (2012). Cities in a world economy. (4th ed.). (Ser. Sociology for a New Century). SAGE Publication, Pine Forge Press: Thousand Oaks, CA, USA.

4. Schofield, P. (2011). City resident attitudes to proposed tourism development and its impacts on the community. International Journal of Tourism Research, 13, 218-233. https://doi.org/10.1002/jtr.814

5. Ramkissoon, H., \& Uysal, M. (2011). The effects of perceived authenticity, information search behaviour, motivation and destination imagery on cultural behavioural intentions of tourists. Current Issues in Tourism, 14, 537-562. https://doi.org/10.1080/13683500.2010.493607

6. Memluk, Murat Z. (2013). Designing Urban Squares. https://doi.org/10.5772/55826

7. Rat, M. M., Gavrilović, M. T., Radak, B. Đ., Bojana, Bokić, S., et al. (2017). Urban flora in the Southeast Europe and its correlation with urbanization. Urban Ecosyst., 20(4), 811-822. https://doi.org/10.1007/s11252-017-0645-6

N. E. Ruzhytska, I. O. Sidorenko

National University of Life and Environmental Sciences of Ukraine, Kyiv, Ukraine

\section{LEGAL REGULATION BY THE USE OF TERRITORIES AT THE HISTORICAL CENTER IN KIEV}

In modern world there is a significant increase in scientific research on improving approaches to the preservation, reconstruction and restoration of historical centers in the structure of the urban environment. The historic part of the city is a real estate that contains very valuable cultural potential and requires specific forms of protection. Exploring the historical data of the urban areas and preserving the sites is a key aspect in improving the city's landscape and spatial potential. The analysis of historical territories should be based on preliminary scientific studies of planning features and typology of historical cities. The historical landscape should be considered as a universal heritage in the structure of the city. The government of the state in whose territory this territory is situated should consider it its duty to protect the heritage and integrate it into modern social life. The historical and archaeological immovable heritage of Kyiv has a variety of sites, which today require additional research and measures regarding the proper and lawful use of the territories within which such sites are located. It is crucial to study the protection status of historical and archeological sites of real estate and the possibility of further use of these territories in the modern urban structure. The research focuses not only on individual architectural landmarks, but also on compositional ensembles, namely old neighborhoods, and large urban complexes in an urban environment. The methods of systematic and comparative analysis are applied in the article. The information base is: legislative documents, historiographical, iconographic and written sources, also the completed materials of field surveys of objects. Studying current approaches to the preservation of historic sites, the embodiment of which will in the future lead to the rational use of territories, and the improvement of economic potential are important issues for the development of the city. In order to solve the problems of preserving and managing the historic territories in the city structure, it is necessary to provide legislative and regulatory measures that will be crucial to ensure the comprehensive universal value of the territories.

Keywords: Conservation; monument; urban environment; cultural heritage; historical and archeological estate; historical center. 